\title{
Profil Klinis dan Laboratoris Infeksi Sitomegalovirus Kongenital di Rumah Sakit Umum Pusat Dr. Sardjito
}

\author{
Ruth Kania Permatasari ${ }^{1}$ Agung Triono, ${ }^{2}$ Eggi Arguni ${ }^{2}$ \\ ${ }^{1}$ Program Pendidikan Dokter Fakultas Kedokteran Kesehatan Masyarakat dan Keperawatan , ${ }^{2}$ Departemen Ilmu Kesehatan Anak \\ Fakultas Kedokteran Kesehatan Masyarakat dan Keperawatan Universitas Gadjah Mada/RSUP Dr. Sardjito, Yogyakarta
}

Latar belakang. Sitomegalovirus (Cytomegalovirus/CMV) kongenital merupakan infeksi yang menimbulkan beban kesehatan yang berat bagi anak dan keluarga. Manifestasi infeksi CMV kongenital, antara lain, jaundice, trombositopenia, mikrosefali dan kalsifikasi intrakranial. Di Indonesia, data mengenai profil klinis dan laboratoris infeksi CMV kongenital belum banyak dilaporkan, terutama di RSUP Dr. Sardjito, Yogyakarta.

Tujuan. Mengetahui profil klinis dan laboratoris infeksi CMV kongenital pada pasien anak di RSUP Dr. Sardjito.

Metode. Penelitian observasional ini dilakukan dengan melihat rekam medis pasien usia kurang dari 2 tahun dengan infeksi CMV kongenital, yang dirawat inap di RSUP Dr. Sardjito dari Januari 2012 sampai Juli 2017.

Hasil. Selama periode penelitian terdapat 36 pasien dengan infeksi CMV kongenital. Manifestasi klinis yang paling mendominasi adalah tetraparesis spastik (12,5\%), mikrosefali (25,81\%), hepatomegali (22,86\%), sensory neural hearing loss (SNHL) (23,81\%), atrofi cerebri (40,00\%), dan kalsifikasi intrakranial (72,73\%). Manifestasi laboratoris ditemukan IgG positif $100 \%$, IgM positif $30,30 \%$, antigenemia positif $100 \%$, anemia 50,00\%, neutropenia 40,00\%, peningkatan SGPT 61,11\%, dan bilirubinemia 75,00\%. Kesimpulan. Manifestasi klinis berdasarkan pemeriksaan klinis yang paling banyak ditemui adalah mikrosefali dan manifestasi laboratoris yang paling banyak ditemui adalah IgG positif dan antigenemia positif. Sari Pediatri 2021;22(5):297-303

Kata kunci: sitomegalovirus, profil klinis, profil laboratoris, anak, deskriptif

\section{Clinical and Laboratory Profiles of Congenital Cytomegalovirus Infection in Dr. Sardjito Hospital}

Ruth Kania Permatasari, Agung Triono, Eggi Arguni

Background. Congenital (CMV) is an infection that raises a heavy health burden for children and families. The examples of CMV congenital infection's manifestation are jaundice, thrombocytopenia, microcephaly, intracranial calcification, and many more. In Indonesia, data about clinical and laboratory profile of CMV congenital infection is insufficiently complete, especially in RSUP Dr. Sardjito, Yogyakarta.

Objectives. This study aimed to know about clinical and laboratory profile of CMV congenital infection in RSUP Dr. Sardjito.

Method. An observational study was conducted by seeing patient's medical record. The subject must be under 2 years old and diagnosed CMV congenital infection and hospitalized in RSUP Dr. Sardjito from January 2012 to July 2017.

Results. During the study period there were 36 patients with congenital CMV infection. The most prominent clinical manifestation are tetraparesis spastic (12,5\%), microcephaly (25,81\%), hepatomegaly $(22,86 \%)$, SNHL (Sensory Neural Hearing Loss) $(23,81 \%)$, atrofi cerebri (40,00\%), intracranial calsification (72,73\%). Laboratory manifestation found positive IgG 100\%, positive IgM $30,30 \%$, positive blood antigenemia (100\%), anemia 50,00\%, neutropenia 40,00\%, increased SGPT 61,11\%, and bilirubinemia $75,00 \%$.

Conclusion. A clinical manifestation which is mostly found from the physical examination is microcephaly and the most found laboratory manifestation is positive IgG and positive antigenemia. Sari Pediatri 2021;22(5):297-303

Keyword: cytomegalovirus (CMV), clinical profile, laboratory profile, children, descriptive

Alamat korespondensi: Agung Triono. Departemen Ilmu Kesehatan Anak Fakultas Kedokteran Kesehatan Masyarakat dan Keperawatan Universitas Gadjah Mada/RSUP Dr. Sardjito, Yogyakarta. Email: agungtrionodr@yahoo.com 
I nfeksi sitomegalovirus (cytomegalovirus/CMV) merupakan suatu infeksi yang sering dialami anak. Seroprevalensi infeksi CMV sangat bervariasi, antara $65 \%$ sampai $90 \%$ pada usia dewasa tengah di Amerika Serikat. ${ }^{1}$ Seroprevalensi berdasarkan wilayah demografi dan ras paling tinggi terjadi di Amerika Selatan, Afrika, dan Asia, dan yang paling rendah terjadi di Eropa Barat dan Amerika Serikat ${ }^{2}$ Untuk di Indonesia sendiri belum ditemukan angka kejadian yang pasti, tetapi prevalensi seropositif pada populasi umum cukup tinggi, yakni sekitar $87,8 \% .^{3}$

Infeksi CMV kongenital dilaporkan pada 0,6\%6,1\% bayi baru lahir. ${ }^{4,5}$ Infeksi CMV kongenital terjadi melalui transmisi plasenta. Transmisi CMV saat masa fetus pada ibu yang belum memiliki imunitas akan menimbulkan manifestasi lebih berat. Manifestasi klinis infeksi CMV kongenital yang muncul bisa bersifat simtomatik dan asimtomatik. ${ }^{2}$ Infeksi yang bersifat simtomatik juga dapat memunculkan manifestasi, seperti kehilangan pendengaran neurosensori, mikrosefalus, gangguan motorik, retardasi mental, korioretinitis, dan gangguan pada gigi. Gejala yang sering muncul adalah gangguan perkembangan saraf yang bersifat jangka panjang. Beberapa tampakan klinis lainnya antara lain adalah munculnya petekie, bayi dengan berat lahir rendah, trombositopenia dan jaundice. ${ }^{1}$

Karena angka kejadian infeksi CMV yang besar, penting untuk mengetahui kasus-kasus CMV yang ada di sekitar kita. Sepanjang pengetahuan peneliti, belum ada penelitian yang menjelaskan tentang profil klinis dan laboratoris infeksi CMV kongenital di RSUP Dr. Sardjito.

\section{Metode}

Penelitian deskriptif dengan studi retrospektif observasional dilakukan dengan melihat rekam medis pasien anak usia kurang dari 2 tahun yang terdiagnosis CMV kongenital yang dirawat di RSUP Dr. Sardjito sejak Januari 2012 sampai Juli 2017. Kriteria inklusi meliputi pasien terdiagnosis CMV kongenital oleh dokter penanggung jawab klinis berdasarkan manifestasi klinis dan pemeriksaan serologi dan tertulis dalam rekam medis, memiliki IgM dan atau antigenemia positif, memiliki data rekam medis yang lengkap, memiliki $\geq 1$ gejala berikut saat lahir: petekie, jaundice dengan hiperbilirubinemia terkonjugasi, kejang, hepatosplenomegali, trombositopenia, mikrosefali, korioretinitis, atau kalsifikasi intrakranial. Tidak terdapat kriteria eksklusi pada penelitian ini. Pengambilan data dilakukan di Instalasi Catatan Medik RSUP Dr. Sardjito pada bulan Agustus-Oktober 2017. Pengambilan data dilakukan cara consecutive sampling. Data dasar subjek penelitian yang dicatat adalah usia, jenis kelamin, diagnosis, manifestasi klinis dan laboratoris. Data kemudian dianalisis menggunakan analisis univariat menggunakan statistic deskriptif (mean, median, dan standar deviasi) yang disajikan dalam bentuk narasi dan tabel. Penelitian telah mendapatkan persetujuan etik dari komisi Etik Bidang Kedokteran dan Kesehatan Fakultas Kedokteran UGM tanggal 28 September 2017 nomor KE/FK/1059/ $\mathrm{EC} / 2017$.

\section{Hasil}

Selama periode penelitian terdapat 36 pasien yang terdiagnosis infeksi CMV kongenital.

Karakteristik pasien ditampilkan dalam Tabel 1. Defisit neurologis yang paling banyak ditemui dalam infeksi CMV kongenital adalah tetraparesis spastik, sedangkan abnormalitas lingkar kepala yang paling banyak ditemui adalah mikrosefali. Hepatomegali lebih banyak ditemukan dibanding dengan splenomegali. Sklera ikterik merupakan gambaran yang umum ditemukan pada pemeriksaan fisik mata. Tidak ada pasien yang dilaporkan mengalami korioretinitis. Berdasarkan hasil pemeriksaan CT scan kepala, atrofi serebri paling sering ditemukan, sedangkan dengan pemeriksaan USG kepala paling banyak ditemukan kalsifikasi intrakranial. Mayoritas subyek dengan gizi baik dan tidak diterapi gansiklovir.

Pada Tabel 2, pasien laki-laki dengan IgM negatif dan IgG positif lebih sering ditemukan. Antigenemia positif ditemukan pada semua pasien. Anemia ditemukan pada 50\% pasien, sedangkan pada pemeriksaan fungsi ginjal peningkatan kadar BUN hanya terjadi pada satu pasien. Pada pemeriksaan petanda kerusakan hati dan fungsi sintesisnya terjadi peningkatan kadar SGOT, SGPT, G-GT, ALP dan APTT serta terjadi hipoalbuminemia. 
Tabel 1. Profil klinis pasien CMV kongenital

\begin{tabular}{|c|c|}
\hline Variabel & Jumlah (\%) \\
\hline \multicolumn{2}{|l|}{ Defisit neurologis $(\mathrm{n}=32)$} \\
\hline Tetraparesis spastik & $4(12,5)$ \\
\hline Peningkatan refleks patologis & $2(6,25)$ \\
\hline Hipertonus & $1(3,13)$ \\
\hline Hipotonus & $1(3,13)$ \\
\hline Speech delayed & $1(3,13)$ \\
\hline Hemiparesis & $1(3,13)$ \\
\hline Kejang & $1(3,13)$ \\
\hline \multicolumn{2}{|l|}{ Lingkar kepala $(\mathrm{n}=31)$} \\
\hline Mikrosefali & $8(25,81)$ \\
\hline Makrosefali & $1(2,26)$ \\
\hline Brachisefali & $1(2,26)$ \\
\hline Plagiosefali & $1(2,26)$ \\
\hline Hepatomegali $(\mathrm{n}=35)$ & $8(22,86)$ \\
\hline Splenomegali $(\mathrm{n}=36)$ & $2(5,56)$ \\
\hline Petekie $(n=1)$ & $1(100)$ \\
\hline Kolestasis/hepatitis & $11(30,55)$ \\
\hline SNHL $(\mathrm{n}=21)$ & $5(23,81)$ \\
\hline \multicolumn{2}{|l|}{ Abnormalitas mata $(n=12)$} \\
\hline Sklera ikterik & $4(33,33)$ \\
\hline Katarak & $3(25,00)$ \\
\hline Makroftalmia & $1(8,33)$ \\
\hline Korioretinitis & 0 \\
\hline \multicolumn{2}{|l|}{ CT scan kepala abnormal $(n=15)$} \\
\hline Atrofi serebri & $6(40)$ \\
\hline Hidrosefali & $3(20)$ \\
\hline Ventrikulomegali & $2(13,33)$ \\
\hline Edema serebri & $2(13,33)$ \\
\hline Ensefalitis & $1(6,67)$ \\
\hline Intracerebral hemorrhage & $1(6,67)$ \\
\hline \multicolumn{2}{|l|}{ USG kepala abnormal $(n=11)$} \\
\hline Kalsifikasi intrakranial & $8(72,73)$ \\
\hline Intracerebral hemorrhage & $1(9,09)$ \\
\hline \multicolumn{2}{|l|}{ Status gizi $(n=25)$} \\
\hline Baik & $19(76,00)$ \\
\hline Kurang & $6(24,00)$ \\
\hline Buruk & 0 \\
\hline \multicolumn{2}{|l|}{ Terapi gansiklovir } \\
\hline Ya & $7(19,40)$ \\
\hline Tidak & $29(80,60)$ \\
\hline
\end{tabular}


Tabel 2. Profil laboratoris pasien CMV kongenital

\begin{tabular}{|c|c|c|}
\hline Variabel & Jumlah (\%) & Rerata \pm SD/Median (minimal-maksimal) \\
\hline Usia (hari) & & $83,50(0-668)$ \\
\hline \multicolumn{3}{|l|}{ Jenis kelamin $(\mathrm{n}=36)$} \\
\hline Laki-laki & $20(55,6)$ & \\
\hline Perempuan & $16(44,4)$ & \\
\hline \multicolumn{3}{|l|}{ Serologi anti CMV, $n=34$} \\
\hline IgM positif, IgG positif & $8(23,52)$ & \\
\hline IgM positif, IgG negatif & 0 & \\
\hline IgM negatif, IgG positif & $26(76,47)$ & \\
\hline IgM negatif, IgG negatif & 0 & \\
\hline \multicolumn{3}{|l|}{ Pemeriksaan antigenemi, $\mathrm{n}=28$} \\
\hline Antigenemia positif & $28(100)$ & \\
\hline \multicolumn{3}{|l|}{ Pemeriksaan darah rutin, $\mathrm{n}=32$} \\
\hline Kadar $\mathrm{Hb}(\mathrm{g} / \mathrm{dL})$ & & $11,27 \pm 2,60$ \\
\hline Anemia & $16(50,00)$ & \\
\hline Jumlah trombosit $\left(\mathrm{sel} / \mathrm{mm}^{3}\right)$ & & $348.733,33 \pm 187.858,15$ \\
\hline Trombositopenia & $4(13,33)$ & \\
\hline Jumlah lekosit (sel/mm³) & & $10.600(3.400-35.360)$ \\
\hline Leukopenia & $3(9,68)$ & \\
\hline Jumlah neutrofil (\%) & & $34,83 \pm 20,02$ \\
\hline Neutropenia & $6(40,00)$ & \\
\hline \multicolumn{3}{|l|}{ Pemeriksaan fungsi ginjal, $n=16$} \\
\hline BUN serum (satuan) & & $5,65 \pm 2,72$ \\
\hline BUN meningkat & $1(6,25)$ & \\
\hline Kreatinin serum (satuan) & & $0,27 \pm 0,09$ \\
\hline Kreatinin meningkat & 0 & \\
\hline Bilirubin total $(\mathrm{mg} / \mathrm{dL})$ & & $18,40 \pm 13,00$ \\
\hline Bilirubinemia total $(\mathrm{n}=8)$ & $6(75,00)$ & \\
\hline SGOT serum $(\mathrm{U} / \mathrm{L}), \mathrm{n}=18$ & & $63,50(21,00-699,00)$ \\
\hline SGOT meningkat & $7(38,89)$ & \\
\hline SGPT serum (U/L), $\mathrm{n}=18$ & & $43,00(5,00-500,00)$ \\
\hline SGPT meningkat & $11(61,11)$ & \\
\hline G-GT serum (U/L), n=8 & & $89,00(39,00-628,00)$ \\
\hline G-GT meningkat & $5(62,50)$ & \\
\hline ALP serum (U/L), n=7 & & $400,00(217,00-1.310,00)$ \\
\hline ALP meningkat & $5(71,43)$ & \\
\hline APTT (detik), n=8 & & $37,05(29,70-64,70)$ \\
\hline APTT meningkat & $3(37,50)$ & \\
\hline Albumin serum $(\mathrm{g} / \mathrm{dL}), \mathrm{n}=7$ & & $3,78 \pm 0,49$ \\
\hline Hipoalbuminemia & $2(28,57)$ & \\
\hline
\end{tabular}




\section{Pembahasan}

Usia merupakan hal yang penting untuk diperhatikan dalam mendiagnosis infeksi CMV kongenital karena berkaitan dengan efektivitas terapi yang diberikan. Idealnya, infeksi CMV kongenital harus terdiagnosis pada usia kurang dari 1 bulan. Hal ini sesuai dengan teori yang menyatakan bahwa untuk mendiagnosis suatu infeksi CMV pemeriksaan harus dilakukan dari minggu pertama sampai minggu ketiga setelah kelahiran karena jika lebih dari itu akan sulit dibedakan apakah kongenital atau akuisita. ${ }^{4}$ Usia saat terdiagnosis ini juga berkaitan dengan terapi. Waktu ideal pemberian gansiklovir adalah dimulai pada usia 28 hari kehidupan, untuk mencegah terjadinya gangguan perkembangan dan gangguan pendengaran di kemudian hari. Semakin cepat terdiagnosis, luaran klinis setelah pengobatan juga akan semakin baik. ${ }^{2}$

Manifestasi klinis yang sering tampak pada pasien dengan infeksi CMV kongenital adalah kehilangan pendengaran neurosensori, mikrosefali, gangguan motorik, korioretinitis, gangguan pada gigi, hepatomegali, splenomegali, jaundice, petechiae, korioretinitis, strabismus, dan atrofi optik. ${ }^{1}$ Berdasarkan hasil penelitian ini, rata-rata pasien hanya mengalami dua manifestasi klinis dari yang telah disebutkan di atas.

Kelainan neurologis dapat disebabkan karena adanya gangguan pada serebral, baik pada saat masih dalam kandungan, pada saat proses melahirkan, atau setelah melahirkan. Sitomegalovirus yang masuk dari darah ibu melalui plasenta ke dalam tubuh janin akan menyebar secara hematogen ke seluruh tubuh termasuk ke cairan serebrospinal. Virus akan masuk ke sistem saraf pusat dengan cara menginfeksi brain microvascular endothelial cells (BMVECs), kemudian akan merusak integritas dari blood brain barrier (BBB), dan dilanjutkan dengan migrasi sel imun yang tidak terkontrol ke parenkim otak sehingga akan menyebabkan inflamasi pada jaringan otak. ${ }^{5}$

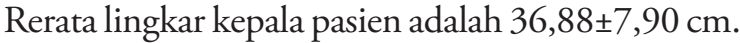
Mikrosefali terdapat pada $25,81 \%$ pasien, lebih sedikit dibanding penelitian lain sejumlah 53\%. ${ }^{6}$ Hepatomegali dan splenomegali ditemukan pada 22,86\% dan 5,6\% pasien. Manifestasi hepatosplenomegali dapat disebabkan karena efek sitopatik CMV yang akan menyebabkan terjadinya perbesaran sel yang terinfeksi CMV yang berujung pada perbesaran organ.

Data mengenai gangguan pendengaran didapat melalui pemeriksaan otoacoustic emission (OAE) dan brainstem evoked response audiometry (BERA). Data SNHL berdasarkan pemeriksaan didapatkan sensitivitas dan spesifisitas BERA lebih tinggi daripada OAE, yaitu 90\% dan 99\% pada anak usia 3 bulan dan $100 \%$ dan $99 \%$ pada anak usia 6 bulan. ${ }^{7}$ Lima pasien $(23,8 \%)$ CMV kongenital mengalami SNHL dan rata-rata pasien memiliki gangguan pada kedua telinga. Pada penelitian lain gangguan pendengaran ditemukan sebesar 21\%-25\% pada bayi baru lahir. ${ }^{8}$ Pasien yang memiliki hasil pemeriksaan OEA atau BERA normal mungkin saja dikarenakan manifestasi yang belum muncul karena beberapa SNHL akan mulai terdeteksi pada usia 27 bulan atau di atas satu tahun. ${ }^{1}$

Kelainan mata berupa katarak ditemukan pada $25 \%$ dan makroftalmia 8,3\%. Penelitian ini tidak menemukan korioretinitis. Penelitian lain melaporkan manifestasi korioretinitis pada $20 \%$ subyek. ${ }^{6}$ Kejadian korioretinitis meningkat pada subjek yang memiliki gangguan sistem imun. ${ }^{9}$

Dari 36 subyek, hanya 15 pasien yang memiliki data CT scan kepala. Atrofi serebri ditemukan pada 40\% dan hidrosefali pada $20 \%$ pasien. Untuk pemeriksaan USG kepala didominasi oleh abnormalitas berupa kalsifikasi intrakranial (88,9\%), sedangkan manifestasi lain yaitu perdarahan intrakranial hanya ditemukan pada 1 subyek $(11,1 \%)$. Kelainan intrakranial yang ditemui menjadi penyebab kelainan neurologis pasien.

Profil laboratoris merupakan hal yang cukup penting dalam menentukan diagnosis. Namun, tidak semua data laboratoris tercantum dalam rekam medik. Pemeriksaan laboratoris yang penting dalam penegakan infeksi CMV kongenital adalah IgG, IgM, dan antigenemia. Antibodi IgG menandakan suatu infeksi laten atau infeksi yang sudah pernah terjadi. Sementara IgM dan antigenemia dapat menentukan diagnosis infeksi CMV yang sedang terjadi, dari 33 pasien yang memiliki data tentang IgM hanya $30,3 \%$ yang positif. Data tentang antigenemia hanya ditemukan 28 data dan $100 \%$ positif. Baku emas untuk diagnosis CMV adalah pemeriksaan kultur virus atau polymerase chain reaction (PCR), tetapi pada saat penelitian ini dilakukan di RSUP Dr. Sardjito belum memiliki fasilitas pemeriksaan PCR. Penelitian lain menunjukkan hasil yang cukup berbeda, yaitu ditemukannya IgM positif pada neonatus yang mengalami infeksi CMV kongenital sebesar 87,5\%, sedangkan $33,3 \%$ pasien hanya memiliki IgG positif 
yang diduga berasal dari antibodi ibu. ${ }^{4}$ Pada penelitian lain mengenai antigenemia pp65 dijelaskan bahwa dari 43 kasus hanya 6 sampel yang memiliki antigenemia positif. ${ }^{10}$

Proporsi pasien CMV kongenital yang mengalami gangguan hepar sebesar 6,6\%,3,5\% mengalami hepatitis dan 3\% kolestasis. ${ }^{11}$ Secara umum, manifestasi infeksi CMV yang sering ditemui adalah mononucleosis like syndrome yang disertai demam, adenopati servikal, dan peningkatan enzim hepar pada pasien imunokompeten. Secara klinis, infeksi CMV yang disertai gangguan hepar sering tanpa keluhan, tetapi sering kali juga dapat disertai dengan adanya jaundice dan distensi abdomen. Sementara secara laboratoris, infeksi CMV dengan gangguan hepar paling sering ditemui adanya peningkatan SGPT. ${ }^{12}$

Diagnosis infeksi CMV kongenital dapat ditegakkan melalui manifestasi klinis lebih dari 1 manifestasi dan memiliki IgM dan atau antigenemia positif. Berdasarkan hasil, banyak subyek yang memiliki manifestasi klinis lebih dari satu gejala, terdiagnosis infeksi CMV kongenital dengan IgM dan atau antigenemia positif. Menurut Center of Disease Control, penegakan diagnosis terbaik untuk infeksi CMV kongenital adalah menggunakan PCR atau kultur virus, sampel yang digunakan adalah saliva atau urin atau darah. Sampel yang dianjurkan adalah saliva, tetapi kultur urin digunakan untuk mengonfirmasi hasil uji karena terkadang saliva dapat terkontaminasi oleh air susu ibu (ASI) sehingga dapat memunculkan hasil positif palsu. ${ }^{4}$

Gansiklovir merupakan terapi utama yang diberikan untuk infeksi CMV kongenital. ${ }^{2}$ Terapi gansiklovir diberikan kepada pasien yang memiliki gejala gangguan central nervous system (CNS), seperti SNHL, gangguan serebral, atau korioretinitis; dan kepada pasien yang memiliki gangguan organ berat, seperti kolestasis, hepatitis, anemia berat, neutropenia, trombositopenia, colitis, atau pneumonitis. ${ }^{13}$

Tidak semua pasien dalam penelitian ini mendapat terapi gansiklovir. Salah satu penyebabnya adalah karena kondisi ekonomi pasien yang tidak memungkinkan. Selain itu juga karena pasien terdiagnosis CMV pada umur yang lebih besar sehingga tidak diterapi. Gansiklovir untuk tatalaksana CMV kongenital paling ideal diberikan pada saat pasien berusia 28 hari. Tujuannya adalah untuk mencegah terjadinya gangguan pendengaran pada usia 6 sampai 12 bulan dan menciptakan luaran neurologis yang lebih baik. ${ }^{13,14}$
Namun, pada penelitian ini masih ditemukan sekitar $31,5 \%$ yang menerima pengobatan di atas usia 6 bulan. $\mathrm{Hal}$ ini dapat terjadi karena keterbatasan rumah sakit dalam memberikan pengobatan sehingga pada saat diagnosis ditegakkan, pengobatan belum langsung dapat diberikan. Selain itu juga karena rujukan dari RS sebelumnya yang kebanyakan terlambat.

Penelitian lain melaporkan bahwa 21 dari 25 (84\%) subyek yang mendapat terapi gansiklovir mengalami perbaikan pendengaran atau tetap memiliki kemampuan mendengar normal pada 6 bulan setelah terapi. ${ }^{15}$ Maka dari itu, pemberian gansiklovir pada periode waktu yang tepat cukup penting diberikan pada pasien infeksi CMV kongenital, karena dapat memberikan luaran yang cukup baik. Durasi pengobatan gansiklovir yang ideal adalah 6 minggu. Terapi lebih dari 6 minggu akan memberikan luaran tidak berbeda dengan pengobatan selama 6 minggu. $^{2}$

\section{Kesimpulan}

Defisit neurologis, kelainan ukuran kepala, kelainan mata, SNHL, atrofi serebri dan kalsifikasi intrakranial, anemia serta trombositopenia merupakan profil klinis dan laboratoris yang dijumpain pada CMV kongenital. Kolestasis merupakan salah satu manifestasi klinis yang sering dijumpai sehingga kolestasis pada bayi baru lahir harus mendapat perhatian klinisi sebagai salah satu kecurigaan adanya CMV kongenital.

\section{Daftar pustaka}

1. Nassetta L, Kimberlin D, Whitley R. Treatment of congenital cytomegalovirus infection: implications for future therapeutic strategies. J Antimicrobiol Chem. 2009;63:862-7.

2. Swanson E, Schleiss M. Congenital cytomegalovirus infection. Pediatr Clin North Am 2013;60:335-49.

3. Lisyani BS. Aspek imunologik dan laboratorik infeksi Cytomegalovirus dan Rubella pada ibu serta neonatus. Simposium penatalaksanaan infeksi virus maternal \& neonatal. Semarang: PERINASIA Cabang Jawa Tengah, 2006.

4. Manicklal S, Emery V, Lazzarotto T, Boppana S, Gupta R. The "silent" global burden of congenital cytomegalovirus. Clin Microbiol Rev 2013;26:86-102.

5. Lanzieri T, Dollard S, Bialek S, Grosse S. Systematic review of the birth prevalence of congenital cytomegalovirus infection in developing countries. Int J Infect Dis. 2014;2: 44-8.

6. CDC Website, Identifying Congenital cytomegalovirus 
(CMV) early in life: information for health care provider. Diunduh pada 28 Mei 2017. Didapat dari https://www.cdc. gov/cmv/downloads/identifying-cmv.pdf.

7. Koyuncu O, Hogue I, Enquist L. Virus Infections in the Nervous System. Cell Host Microbe 2013;13:379-93.

8. Boppana S, Ross S, Fowler K. Congenital cytomegalovirus infection: clinical outcome. Clin Infect Dis 2013;57(suppl 4):S178-81.

9. Bhatt J, Kuchhal V, Saklani K, Kumar V. Accuracy of OAE and BERA to detect the incidence of hearing loss in newborn. J Evol Med Dental Sci 2015;4:8466-74.

10. Tagami M, Honda S, Morioka I, Iijima K, Yamada $\mathrm{H}$, Nakamura M. An unusual case of congenital cytomegalovirus infection-related retinopathy. BMC Ophthalmol 2016;16:81

11. Neto E, Rubin R, Schulte J, Giugliani R. Newborn Screening for Congenital Infectious Diseases. Emerg Infect Dis 2004;10:1069-73.

12. Sakamaki H, Yuasa K, Goto H, Tanikawa S, Akiyama H, Onozawa Y, Okamoto R, Maeda Y, Sasaki T, Kaku H, Takamoto S. Comparison of cytomegalovirus (CMV) antigenemia and CMV in bronchoalveolar lavage fluid for diagnosis of CMV pulmonary infection after bone marrow transplantation. Bone Marrow Transplant 1997;20:143-7.

13. Bilavsky E, Schwarz M, Bar-Sever Z, Pardo J, Amir J. Hepatic involvement in congenital cytomegalovirus infection infrequent yet significant. J Viral Hepat 2014;22:763-8.

14. Tezer H, Kanik Yüksek S, Gülhan B, Özkaya Parlakay A, Tuna Kirsaçlioğlu C. Cytomegalovirus hepatitis in 49 pediatric patients with normal immunity. Turkish J Med Sci 2016;46:1629-33.

15. Kadambari S, Williams E, Luck S, Griffiths P, Sharland M. Evidence based management guidelines for the detection and treatment of congenital CMV. Early Hum Dev 2011;87:723-8.

16. Kimberlin D, Lin C, Sánchez P, dkk. National Institute of Allergy and Infectious Diseases Collaborative Antiviral Study Group. Effect of ganciclovir therapy on hearing in symptomatic congenital cytomegalovirus disease involving the central nervous system: a randomized, controlled trial. J Pediatr 2003;143:16-25.

17. Smets K, De Coen K, Dhooge I, dkk. Selecting neonates with congenital cytomegalovirus infection for ganciclovir therapy. Eur J Pediatr 2006;165:885-90. 